\title{
Continuity and Change: Hispanic Musical Influence in the Philippines
}

\author{
Rosalina L. Divinagracia \\ Mindanao State University at Naawan \\ Integrated Developmental School \\ Philippines
}

\begin{abstract}
Hispanic musical influences marked a significant change in the Music History of the Filipino people. This paper traces various music forms, styles, and cultural significance during the Pre-Hispanic period defining the traditional purpose, musical elements, and usage in cultural context. It also discusses the concept of Spanish acculturated musical forms with issues embedded on the infusion and imposition of Spanish music into traditional music for the spread of Christianity. This paper also assesses the changes in music from the 16th - to the late 18th century, particularly on modes of transmission and continuing developments of some indigenous traditions with the assimilated forms of music brought by the Spaniards and the music that survived until the $21^{\text {st }}$ century Filipino musical performances.
\end{abstract}

Keywords: Musical influence, Music Genre, Festivals

\section{Introduction}

To a common listener, the music in Filipino Festivals including rituals, vocal, and instrumental performances is quintessentially Filipino. However, this event is not right. A musical connoisseur will find a fusion of Pre-Hispanic music and Spanish music. The three hundred thirty three years of the Spanish colonization of the Philippines shaped elements of modern Filipino Festival music. It has affected many aspects of Filipino life, including music, and these influences vary in their effects among the different regions of the country. Filipinos had always produced indigenous music, varying by region, and much integrated with their daily lives. There were work songs, ritual songs to control the forces of nature, as they understood them, lament songs, and songs to celebrate special occasions. Most singing was unaccompanied, although indigenous instruments were used to accompany some singing and dance. In addition to the enforced musical participation in the liturgy, musical influences in other genres flourished, including vocal secular music, religious-themed (but non-ritual) musical plays, and instrumental genres.

Dominantly, the primary goal of the Spanish colonizers was to introduce Christianity to the country, this was not the only goal. Filipinos of all ages learned how to sing the Latin or Spanish liturgical responses. Learning and singing responsorial, antiphonal, or unison ritual sections was a requirement for this imported spirituality. From this obligatory spiritual introduction, the foreign influences began to permeate other cultural practices and musicality of the people. Those who did not comply and acculturate were termed "indios" or "mangmang" (derogatory word for idiots). These insults of indigenous traditions enforced compliance and obedience to the "Christian way," however people might silently resist.

Although the Spanish influence permeated the arts of some regions of the country (particularly lowland Luzon and the more populated areas of the Visayas), indigenous traditions survived, and some Filipinos resisted the acculturated forms as foreign to their beliefs and traditions. How has this musical forms sustained throughout the years? Despite the Spanish imposition of Christianity on native culture, this paper further argues that the traditional beliefs were still preserved through oral transmission. This allowed for the continuity of their traditional musical forms, albeit with Spanish influences.

\section{Musical Forms: Pre-Hispanic Period}

Tracing back the emergence of music and the development of cultural music during the Pre-Hispanic Period is a complex task. Filipinos have a strong and well-developed ritualistic musical practice in a form of chanting, dancing, and indigenous instrumental playing. Ananayo (2007), from Ifugao, Northern Philippine discussed the traditional practices in the upland involving the chanting of genealogy, and the second wake in recognition of the dead. ${ }^{1}$ In this event, the cultural identity of the Ifugao creates a mythical character of believing in a very significant traditional belief.

\footnotetext{
${ }^{1}$ It is done by removing the bones of the dead (one year old prior from death) wrapped in a special traditional cloth while they offer the biggest pig of good lung and heart.
} 
With the rituals, singing and reflecting on the past life is done while the Mumbaki (traditional Ritualist/ Shaman) recites and chant the genealogy as a sign of heroic deeds and honor of the past generations of the dead's lineage. This evidence of ritualistic events showed a strong conviction to the local Gods where music played a crucial role during the ceremony including chanting and recitation of genealogies. As people gathered to participate in the event, portrayed unity and regionalism is evident by every occupation in the community.

To their human experience and practice, the chant singing evokes the spirits in thanksgiving and praise, and for protection and blessing. It uses an expression of deep vocal vibration that identifies melisma, call and response and free rhythm. Unlike in Western music, indigenous notations are not definite instead; it represents the identity as the Upland people with the tonal system used (the use of pentatonic scale).

In the same manner, Jose Maceda's ethno musicological approach showed a distinct characteristic of music in the mountainous areas of Northern Luzon, in coastal and in inner areas of Mindanao, Sulu, and other islands. He describes the musical characteristics of the Pre-Hispanic era as Malaysian-type music "associated with village feasts, individual and family activities, a belief in spirits (anito), and influenced by the syntax of Malaysian language." The emphasis in music pictures different dimensions in life; the important feast where people gather for merry-making; recreational and daily activity music that gives humankind an opportunity to play a musical instrument and sing individually; and those involved in the healing process between the healer and the ill person (Maceda 1971).

Moving towards the South, the accounts of Brandeis (1993), cited musical forms found in Bukidnon for both male and female singer performer. For most tribal celebrations, chanting, song-speeches and praying relate to the ceremony (kaliga). The Bukidnons have idangdang (ballads), limbay (improvised songs), and salâ (improvised singing of the Talaandig) expressed in mellismatic phrasing, very high pitch at the highest volume possible, rubato style and strictly metered style. The tonal system used pentatonic melodies repeated in several times with some variations. However, the length varies into two distinct parts separated by breath break.

In other parts of the South, Del Valle (1998), provides accounts of the Islamic Vocal Music in Mindanao classified as old or new (for Maranao); with or without accompaniment (for Tausug); while others classify songs according to their functions. The songs possess a tense, high pitched mellismatic long phrases characteristic for epics, long narratives, and liturgical chants. These are broadly categorized as formal (requiring professional trained singers to perform epic, narratives, religious songs and chants, and rite of passage) and the informal (layman songs, children's songs, games, lullabies, love songs, and work songs). Specifically the Maranao have: kandurangen (relating to Darangen epic), kambayoka (singing style of a very long dialogue for 2 or more performers), kapronan (songs about pathos), kandomana (religious stories from Kisa) and idaida (ordinary songs); Tausug have: lugo (religious ritual), pagabang (entertainment songs accompanied by a gabbang), and sindil (love dialogue song entertainment); and Maguindanao have: tudtol (long narrative), bayok and sindil (Islamic religious chants).

Under the expedition of Antonio Pigafetta to the Philippines, "The Lowland Christian Philippines" shows a thriving musical tradition classified into genres and emphasized the nature of musical genre according to their purpose and uses. $^{2}$ The accounts focus on the general descriptive significant role of musical forms practiced to every community. Evidences showed that, where vocal and literary works are present, there are strong ties to superstitious beliefs and to their traditional beliefs. Similarly, in other parts in the Philippine, there were continued practices to the singing to the anito (belief in spirits) where it calls for a celebration involving both vocal and instrumental musical forms like that of the Igorot in the North and the T'boli in the southern part.

Another aspect of traditional rituals showing the power of a vocal form is that of from the Iraya. ${ }^{3}$ In Baes's research, he describes the significance of the marayaw. ${ }^{4}$ Belief states that the marayaw is one of the vocal genres referring to the prayers to the ancestors. However, the song is said to be a lullaby that is sung by Aletawu ${ }^{5}$. Later it was associated with the powerful spirit rituals for curing disease and casting magic spells (Baes 1988). In this context, the connection between animism and vocal singing is strong. However, the concept of singing the lullaby style used in prayers seems reflective to the effects of calmness and quietness of melodic lines associated to lull a child to sleep. This belief found in most lowland rural areas in the Philippine are strong in spirit rituals and celebration.

\footnotetext{
${ }^{2}$ Corazon C. Dioquino, The Lowland Christian Philippines, Garland Encyclopedia of World Music: Southeast Asia. Miller,

Terry E and Sean Williams (eds.) (New York), Garland Publishing), p. 839.

${ }^{3}$ semi-nomadic like gypsy in nature of Mindoro, Philippines. It could also mean man or human being.

4 a ritualistic power song utilized for healing the sick and for casting magical spells

5 invokes the powerful earth spirits for his aid
} 
It also depicts a trance music that mediates the spirit of another world from the real world. The villagers accept the "healer" as the extraordinary being not a mere practitioner of rituals but was trained by an experienced healer.

As traditions scattered throughout the archipelago, including ritual belief practices, developments in instruments used in the celebration are also striking in reaching the significant goal in music. Commonly the use of gongs, stamping tubes, buzzes, plucked lute (gitada), zithers, jew's harp, panpipes, flutes, and drums are evident (Dioquino 1982). Like the singing of high pitches of the vocal form, instruments possess an element of producing extremely loud sound to drive away the bad spirits and welcome the good. Even to date, in lowland Philippines, the use of tin cans, making noise and playing very loud music right before the New Year eve still exist.

Aside from the belief in spirits and the prevalent use of instruments, the intoxication of the gangsa (flat gong) in a continued joyous atmosphere provided an interlocking effect that makes a sense of the feast atmosphere. As an outdoor event, people enjoyed music making, instrumental playing as well as dancing. However, in an exclusive manner, nose flute and bamboo zithers are common within the family setting and not so much in big crowds. Nose flute is a communicative instrument among people, lovers, and even children while bamboo zithers depict a melancholic soft and tiny sound. ${ }^{6}$ Both instruments express an entertaining effect as well as a welcome for visitors.

For some Northern indigenous people like the Negritos (little Negroes) in Luzon and other mountainous areas in Mindanao and Negros Oriental evidences showed numerous collections of chordophones (instruments made of strings) which later resembles the guitars. The plucked kabungbung (bamboo zither), traditional guitar using abaca hemp for the strings, kulasseng (bamboo fiddle) as their common instrument which in Capiz they call it litgit (another name of bamboo fiddle), and butting (musical bow). Interestingly, these stringed instruments produce instrumental music for the dance as well as music making of the Negritos (Espina 1961). The principle of gathering and merry-making suggests the typical character of Filipinos.

The transformation of the Pre-Hispanic music in recent musical styles into modern harmonies and jazz are results of modernization brought by different medium. Technology attributes to the changing representations in music, however; influences of colonization for several years take most part of the transformation.

\section{Musical Forms: Hispanic Period}

The coming of the Spaniards in the Philippines brought an influx of Western changes as coined to religious conversion from 1500s to 1800s. People gathered around for feasting and games. Later, the friars directly introduce Gregorian chant and polyphony as a new musical language to the Indus (Spanish term for natives). In later 1500s, widespread establishment of schools (The Franciscan Order, The Jesuit Order, Augustinian Order, and schools for prospect ruling families) that focused in the teachings of liturgy and accompanying music for boys. This includes singing and playing musical instruments like organ, and flutes as useful in the church liturgy (Dioquino 1998).

In addition, the teachings of the plainsong (monophonic liturgical music) were prevalent in most churches as it was developed for the fulfillment of the Spaniards desire to spread the religion throughout the country. Even though the plainchant is taught in a cappella (unaccompanied singing), the learners were also taught to sing it with organ accompaniment. In addition to this development in music, dances and manufactured instruments (organ, flute, harp, guitar and others) were introduced. ${ }^{7}$

The choir is developed and played an important role in the exposition of the messages in the bible as employed during the mass. (Boromeo 1991). This development is dominant in all major sections in the services of the church. The order of the liturgical services where the choir sings is as follows; it starts with triumphant entry where the choir sings the majestic songs, then the singing of Credo, Gloria, Alleluia, Psalms, Offertory songs, Communion, and the Recessional songs. To date, these practices in the church are still intact during services.

The Hispanic influences found in lowland Philippines mark the beginning of changes in the lives of many Filipinos. The friars amalgamate indigenous traditional practices onto the church celebrations of which many of them still exists to recent practices. These practices include some Mediterranean-type solo song (with guitar accompaniment); Ritualistic practices: pre contact rituals continued with an overlay of catholic influence like festivities Sinulog, Atiatihan, Pasyon, Flores de Mayo, Daigon, and Pastores. There is also evidence of musical structure in major or minor tonalities, $3 / 4$ and $4 / 4$ meters harmonies as opposed to the monophonic, and free rhythms of the traditional practices.

\footnotetext{
${ }^{6}$ Jose M. Maceda Means of Preservation and Diffusion of Traditional Music:ThePhilippine Situation, Asian Music,(Vol. 2, No. 1 1971), p. 15.

${ }^{7}$ Emma Helen Blair and Robertson, James Robertson, The Philippine Islands 1493-1803, vol 16, (Cleveland: Arthur Clark Company 1903-1909) p. 152.
} 
Bowen articulated his views that "The Philippines has indeed become a site for a new style of "experience-near" accounts of cultural forms and social lives." This experience is part of the form of what culture takes (Bowen 1995). Essentially, the changes in the solemnity of the worship transform into some kind of provincial identity as a tourist attraction. It is re-affirmed by Ness (1992), as she "traces the transformations in a specific type of dance from private worship to a celebration of the provincial identity of Cebu." Evidently, the Sinulog festival is commercially becoming an attraction for tourists less the real relevance of the panata (oath). The festival features an extravagant display of colorful costumes and majestic music with multiple rhythms.

Another similar festival is the Ati-atihan, "recalls the transmission of political power from an aboriginal black population to the immigrant Southern Mongoloid population (original Australoid population of Panay)" (De Raedt 1977). From this account, Domingo (1996), describes the details of Ati-atihan in the town of Kalibo, Aklan Panay as the wildest among the festivals in the country.

Despite the famous celebrations in Kalibo Aklan, it was acknowledged by historians that, Sto. Niño was first presented to Juana, the Queen of Cebu in 1521. From then on, it became the Catholics observance of prayers, processions, parades, dancing, and merrymaking. ${ }^{8}$

Another form of religious expression, meditation and reflection in a form of festivity is during Lent Season. One of them is the pabasa (the chanting of the pasyon). It depicts the commemoration of the Lord's Passion, Death and Resurrection. Historically, Pasyon is one of the many influences of the Spanish Christianization and colonization. It refers to the text musical setting of the Lord's Passion, Death and Resurrection verses. In the Tagalog region, pasyon is the text while pabasa is the chant (Aligan 2001).

Furthermore, Aligan (2001), emphasized that Pasyon's musical aspects, in most times, chanted or sung poetry during Spanish times. It is characterized by the regular rhyme having an effect of "plaintive tonal quality." Aside from its regularity of meter, it shows the romantic agony found in songs like dalit (sentimental nature of the folk and indication of certain agony). Despite the predominating Spanish melodic influence, tagulaylay (one style particular to the Pasyon which is a recitative lament) showed the complete chanted stanza in one breath with fancy curls and thrills.

In the account of Espina (1961), Pasyon spelled as Pasión has a chant like character, with more florid passages that is common in Southern Leyte, sung to two of the several tunes among the 580 verses bearing the Spanish title of Nuestro Señor Jesucristo. The song, sung in a cappella, usually harmonized mostly in running parallel thirds to the melody. "Other techniques include glissando, performed loudly, and several melodies are sung without a definite pattern as to their occurrence in the song."

The heavy emotions of the Lenten Season balances a merrymaking celebration, the Flores de Mayo (literally means flowers of May). This new musical form developed around the new religious and secular activities stressed out by Lucresia Kasilag. The Flores de Mayo is one of the annual celebrations with special songs for the Blessed Virgin Mary (Kasilag 2001).

Towards the end of Flores de Mayo is the Santacruzan. It highlights the celebration with the parade of beautiful ladies in their respective assigned Reyna (queen) names representative of their beauty. While the children offer flowers to the Virgin Mary, the choir (cantores) chants continuously the "Dios Te Salve," selected participants paraded in a form of a pageant. The selection of stars is based on the embodiment of traditional feminine qualities and not merely by looks. Almost every town from the dirt road barrio honors beautiful Philippine maidens and their handsome escorts under the hand-carried bamboo arch decorated with fragrant flowers (Yalong 2014).

Other Secular songs that are not included are the tagulaylay, a recitative lament; the awit, a chanted story based on the crusades; and the kumintang, a war song, now known as a love song. Stage plays that developed are, the Moro-Moro, with a stereotyped theme depicting encounters between Muslims and Christians; the Duplo, a form usually performed during the ninth day of a series of prayers; the cenaculo, a drama of the Passion and death of Christ; and the Carillo, a shadow play with suspended cardboard figures. These forms are developed in the Spanish period and yet important in the musical Diasporas (Pffeifer 1976).

Another Spanish Era choral tradition was the earliest Christmas the cumbancheros, or groups of children known as the 'marines" in the night. ${ }^{9}$ This is one of the Filipino choral practices that have continued until today. The children share happiness through the songs and at the same time, earn small amounts of money for merienda (snacks). Some of their traditional music endures to the present.

\footnotetext{
${ }^{8}$ Reuben Domingo, The Ati-Atihan Festival in Hector Santos, ed., Philippine History and Culture Series; U.S.A. 1996.

${ }^{9}$ Alejandro Roces, Fiesta, (Hongkong: Vera-Reyes, Inc, 1980), p.208.
} 
In the Visayas region in the Philippines, "cumbancheros" is a relative term to daygon, a Cebuano Christmas caroling repertory, and a yearly tradition in Cebu and all over the region in Lowland Philippines. Groups walk from houses to houses singing Christmas songs and /or playing instruments to collect some type of tribute along the way. Singers with guitars and bandurias are the most common stringed ensemble, but almost any instrument or group of instruments used. $^{10}$

One of the earliest forms of daygon still exist is the pastores, an orally transmitted Hispanised genre depicting the story of the Nativity, both acted out in dance, and sung in Bisayan (in Cebu), "Guitars, and tambourines supply the accompaniment while the dancers execute staccato and syncopated rhythms with castanets" (Espina 1961).

In Southwest part of the Philippine island chain, Cuyonon (formerly Cuyo) is known for the Tambora performances, a similar version of the pastores. It is a depiction of the nativity, traditionally performed by Christmas carolers in Cuyunon or Spanish. Native Yuletide songs such as the "Pinagbalay," "Pastores," and "Tambora," are being replaced by modern Christmas carols. Of Cuyo's festivity music, among the well preserved are the songs and chants of the Ati (Fernandez 1975).

Another religious festivity of the Pastores is found in Bicol. The Pastores Bicol folk festival in Legazpi City offers carol singing with different scenery. They are dressed as the shepherds who came to rejoice at the birth of Jesus in Bethlehem, young people (or pastores) dance through the city singing songs and dancing Christmas folk dances, accompanied by traditional musikeros (musicians). Aside from the pastores other forms of festivities in Advent Season flourished. It is common in the Tagalog areas. These are panunuluyan, pananawagan, pananapatan in Tagalog areas (elaborate outdoor drama in various names). ${ }^{11}$

Most of the early developments are related to the vocal genres in and outside the church. For example, the singing of the kundiman, kumintang and the balitaw are few of those famous influences. In 1800s, kundiman, a popular lyrical love song were composed in Western idiom. Dioquino emphasized the beginning minor key that shifted to major key at the second half of the song. The text of the song depicts romantic love, portrayal of faith, willingness to sacrifice for a loved one, and a way to express patriotic sentiments (Dioquino 1982).

Bañas (1969), cites three theories regarding the origin of Kundiman. First, it was derived from the phrase "kung hindi man" (if not so). Second, it was taken from the excerpt of Hele hele nang kandungan/ Hele hele ng kundiman (Hush hush the cradle, Hush hush the kundiman). Third, from the accounts of Norberto Romualdez and Consejo Cauayani (1954), who referred the kundiman to the red cloth worn by male dancers or mainly men in the countryside. This account of the red cloth affirmed when the song "Mula Nang Mauso, Damit ng Kundiman" (Eversince the Cloth Kundiman Become a Fad) was popularized in Cavite.

The kumintang was a song which Paterno (1890), says was quite typical of Philippine culture at the arrival of the Spaniards while Santiago (1931), accounts this as a war song from the start, and later lost its fight and became rather plaintive then later pantomimic. It was both a dance and a type of song at the same time and its origins traced to the province of Batangas. There are three classes of kumintang reported: kumintang of conquest, bridal kumintang, and the kumintang in a form of musical recitations and in the awit (song). ${ }^{12}$

Another famous love song identified from the Visayas and Mindanao, the balitaw. Characteristically, it has a Malayan temperament and mood (Espina 1961). However, Walls (1892), discusses that in other parts of the Visayas balitaw become one of the most popular dances in the Philippines. Like kumintang and kundiman, balitaw is accompanied by guitar while men usually sung the genre. Later developments showed evidences of these genres arranged in choral compositions and accompanied by piano, organ, electronic instruments, and combo (band) or the band orchestra. The new breed musicians with the new form of Spanish-influence was also acquainted to play musical instruments that accompany the singing or dancing. These include the guitar, harp, rondalla, and the brass band.

First, the Filipino guitar considered the most widely used instrument that accompanies the singing. It consists of six strings that enable the guitarist to pluck, strum, or pick. As introduced by the Spanish colonization, the guitar is often heard in social gatherings, neighborhood hangouts, and even in rural areas where music making is their favorite past time.

\footnotetext{
${ }^{10}$ Espina, Beaunoni A. Espina Music in the Philippines, and the Development of Sacred Music There. Thesis (Ph.D.), Union Theological Seminary, (New York City), 1961, p. 236.

${ }^{11}$ Roces, Fiesta, p. 203.

${ }^{12}$ Pedro A. Paterno, Los Itas. (Madrid: Sucesores de Cuesta, 1890), p. 210-211.
} 
Second, the harp are believed to have originated from Spanish Renaissance era harps brought to Latin America, then brought to the Philippines through the galleon trade in the late $16^{\text {th }}$ century. Its main purpose in music is to double the voices or fill in the missing voices of the vocal parts. In many hispanized areas in the Visayas, Philippines, the harp commonly played at any events playing folk tunes like; kuratsa, kuradang, and the balitaw while in the Lowland North of the Philippines, the rigodon, pandango, jota, various waltzes, polkas, and other European influences (Grauberger 1991).

Third, the rondalla refers to an instrumental organization of string band originated in Spain. For the standard instrumentation for the Spanish extudientina are as follows; mandolin, violins, guitars, flutes, cellos, basses, tambourines, castanets, and triangles (Pffeifer 1976). However, in Molina's account, Filipino rondalla consists of the following plucked string instruments: banduria (a hybrid of the guitar), laud (tear shaped instrument), octavina (has six sets of double strings, and played with a plectrum), guitarra (guitar), and bajo de uñas (four stringed bass with a plectrum) (Molina 1967). Dioquino (1988), added that the number of players varies from eight to thirty people. They have a repertoire of folk songs arranged in Baroque style for lute and guitar. The difference in the organization of the instruments in the rondalla may attribute to the availability of the instruments. Aside from the availability of commercial instruments, some of the groups cannot afford to purchase the instruments. It is also upon the discretion of the conductor's taste of which instruments he would like to include in his group.

After several instrumental developments, came the band. Every town in the Philippines has their own marching bands. In the same manner, schools from Primary to Tertiary level organized the drum and bugle for parade purposes while in other schools and institutions marching it is used for Military training. Aside from the scholastic activity of the band, the church also employs the group as it leads and accompanies the procession. Furthermore, Diana is common for the town fiesta, the band played several marching music around the town to wake people up to prepare for mass and for the big feast.

\section{Later Continuation of Acculturation Forces and Endurance of Tradition}

With the coming of the Spaniards and the influx of influences, develop an identity that processes the Filipino people. Later, the continuation of acculturation forces and endurance of traditions is evident. The numerous accounts by historians, ethnographers, sociologists, anthropologists, musicologists and ethnomusicologists prove the transformation of music from the Pre-Hispanic era to the Hispanic Period and beyond. Tendencies of innovation in music from both Pre-Hispanic era and Hispanic period prove its lead. The use of keyboard and electronic instruments to mimic the sound of indigenous and acculturated instruments are among those transformations.

After the three centuries of Spanish colonization, musical influences gave way to the changing mores brought by the Americans. First, the Western style of singing (from hymns to simple tunes) coming from Europe and America. It reaches throughout the country, even in places where Spanish colonization is strong. Second, the opening of conservatories including the specialized curriculum in music leads to numerous transformations. To enumerate, studies in piano, music theory, harmony, counterpoint, orchestration, and composition (Santos 1991). In addition, the position of the band is upgraded with the additional categories of studies that includes violin solos, voices, religious music, chamber music and opera. ${ }^{13}$

Among the formally trained Filipino composers and their archetypes; are Rosalina Abejo's Pagtubos (Redemption), oratorio, Thanatopsis, symphony, and Octet, for Winds and Strings; Hilarion Rubio's Florante at Laura (Florante and Laura), overture, To the Filipino Youth, cantata, and Panamin Concerto for cello and orchestra; Ramon Tapales' Ave Liberator for chorus, Messe en stile antico, mass, and Philippine Suite for orchestra. These archetype works of the composers are using folk themes in their compositions that Santos (2005), connotes that "many of whom founded the League of Filipino Composers in 1955 to underscore the importance of creating a body of Filipino classical music."

The use of Hispanic melodic themes rooted from the Pre-Hispanic period into new musical styles are contained in the works of some composers and performers, namely; Ferdinand Pascual Aguilar, Teresita Agana-Santos, Ma. Josefina Albert Pacis, Jose Iñigo Homer Lacambra Ayala, Otoniel Aurelio Gonzaga, Gary Gamutan Granada, Jose Monserrat Maceda, Mabuhay Singers. These musicians are popularizing new forms of art in music and styles where it reaches the international audience. They are expressing musical tastes in etho- pop, pop-rock, jazz and even the classic arrangements of the folk themes (Miller 1998). The continued practices of Sinulog, Ati-atihan, Pasyon, Daigon, Flores de Mayo, Pastores and some musical ritual practices relating to the curing of the sick are also reaching the international market. It is evident in the changes of setting, music delivery and extravagant performances used as a tourist attraction.

\footnotetext{
${ }^{13}$ William R. Pffeifer, Indigenous, Folk, Modern Filipino Music (Dumaguete City: Silliman Music Foundation, Inc., 1976), p. 150.
} 
One of the changes is the use of colorful costuming and acrobatic styles of dancing that entices the audience to participate in the events.

\section{Conclusion}

This paper has offered the continuity and change of the musical Hispanic influences that affected the traditional Filipino mores and values of the three hundred thirty three years of the Spanish colonization of the Philippines. Many aspects of Filipino life, including music, and these influences vary in their effects among the different regions of the country are affected.

The discussion of the identity of a different musical genre from religious practices and festivities down to the instruments brought from Spain has attempted to resemble a representation of music considered to be among the high arts based from the inculcated idea of Christianity. Through this, it is not a question of who plays the music but importantly the concern of how indigenous traditions survived, how the music is imparted, and performed in conformity of the culture it represents. For several accounts, Filipinos resisted the acculturated forms as foreign to their beliefs and traditions. This belief strengthens the aesthetics in the preservation of oral traditions.

Indeed, I argue that though Hispanic influences in music are accepted locally and internationally, it is innovated and changed, to negotiate the identity of the Filipino people as it continue to evolve in the modernized world.

\section{References}

Aligan, Rodel E. (2001). Pasyon. UST Publishing House España, Manila.

Ananayo, Jovel (2007). Interview, University of Hawaii at Manoa

Aquino, Belinda, Dean T. Alegado, and University of Hawaii at Manoa. Center for Philippine Studies (1992). The Age of Discovery : Impact on Philippine Culture and Society. Honolulu: Center for Philippine Studies, School of Hawaiian and Asian Studies, University of Hawaii at Manoa.

Baes, Jonas (1988). "Marayaw" and the Changing Context of Power among the Iraya of Mindoro, Philippines (in Conference Papers/ Referati) International Review of the Aesthetics and Sociology of Music, Vol. 19, No. 2:259-267.

(1987). Ya-Ye-Yo-Na-I-Yu-Nan: Swaying in the Vocal Music of the Iraya People of Mindoro, Philippines, Ethnomusicology, Vol. 31, Indiana.

Bayan, Ruby (2003). Flores de Mayo at Santacruzan.

Blair, Emma Helen and Robertson, James (1903-1909). The Philippine Islands 1493-1803. 55 vols. Cleveland: Arthur Clark Company.

Bowen, John R. (1995). The Forms Culture takes: A State-of-the-Field Essay on the Anthropology of Southeast Asia. The Journal of Asian Studies, vol.54:1047-1078.

Brandeis Hans (1993). Music and Dance of the Bukidnon of Mindanao-A Short Introduction, Filipino Association of Berlin.

Canlas, MC. (2007). Flores de Mayo and the Asian Heritage Celebration. Asian Week: The Voice of the Asian American. San Francisco CA.

Cole, Fay-Cooper (1945).Central Mindanao-The Country and Its People. The Far Eastern Quarterly, Vol. 4, No. 2:109-118.

Del Valle, Leticia G. (1998). Compendium of the Humanities of the Philippines. Musical Arts, National Research Council of the Philippines, General Santos Avenue, Bicutan Taguig, 1631 Metro Manila Philippines, 46-62.

Domingo, Reuben (1996).The Ati-Atihan Festival in Hector Santos, ed., Philippine History and Culture Series; US.

Dioquino, Corazon C. (1982). Musicology in the Philippines. Acta Musicologica 54(1/2): 124-147.

(1998). The Lowland Christian Philippines, Garland Encyclopedia of World Music:Southeast Asia. Miller, Terry E and Sean Williams (eds.) New York: Garland Publishing.

Espina, Beaunoni A (1961). Music in the Philippines, and the Development of Sacred Music There. Thesis (Ph.D.), Union Theological Seminary, New York City.

Fernandez, Fe Tria and Jose T. Fernandez (1975). Makaranta Kita: A Compilation of Cuyuno Songs.

Kasilag, Lucresia R. (2001). Philippines: Western Art Music, The New Grove Dictionary of Music and Musicians, ed. S. Sadie and J. Tyrrell. London: Macmillan. xxii, 577-604.

Maceda, José (1984). A Cure of the Sick "bpagipat" in Dulawan, Cotabato (Philippines)Acta Musicologica, Vol. 56, Fasc. 1, p92-105.

(1971). Means of Preservation and Diffusion of Traditional Music: The Philippine Situation, Asian Music ,Vol. 2, No. 1, pp. 14-17. 
(1979). A Search for an Old and a New Music in Southeast Asia , Acta Musicologica > Vol. 51, Fasc. 1, p160168.

(1990). In Search of a Source of Pentatonic Hemitonic and Anhemitonic Scales in Southeast Asia, Acta Musicologica,Vol. 62, Fasc. 2/3, p192-223.

Manalansan, Martin F. IV (2000). Queer Diasporas,ed. Cyndy Patton and Benigno Sanchez-Eppler. Durham,N.C.Duke University Press.

Molina, Antonio (1967). Music of the Philippines, Manila, National Museum.

Ness, Sally Ann (1992). Body, Movement, and Culture: Kinesthetic and Visual Symbolism in a Philippine Community. Philadelphia: University of Pennysylvania Press.

Paterno, Pedro A. (1890). Los Itas. Madrid Sucesores de Cuesta.

Pffeifer, William R. (1976). Indigenous, Folk, Modern Filipino Music, Dumaguete City, Silliman Music Foundation.

Philippines. Bureau of Public Schools.The Filipino spirit in songs. Manila.

Manila. Roces, Alejandro (1980). Fiesta, Hongkong: Vera-Reyes, Inc. (1962). The Filipino soul in song,

Santiago, Francisco (1931). The Development of Music in the Philippine Islands, Manila: Institute of Pacific Relations.

Santos, Ramon P. (2005).Tunugan : Four Essays on Filipino Music. Quezon City: University of the Philippines Press.

Tiongson, Lito, Elena Rivera Mirano, and Cultural Center of the Philippines. (1992). Musika a documentary on the Spanish influence on Philippine music. [Philippines]: Sentrong Pangkultura ng Pilipinas.

Trimillos, Ricardo D. (1986) Music and Ethnic Identity: Strategies among Overseas Filipino Youth Yearbook for Traditional Music, Vol. 18, 9-20.

(1987). Time-Distance and Melodic Models in Improvisation among the Tausug of the Southern Philippines, Yearbook for Traditional Music, Vol. 19,p23-35.

Veneración, Andrea (1967). International Music Symposium, Ethnomusicology, Vol. 11, No. 1, p107-113.

Walls y Merino, Manuel (1892). LA MUsica Popular de Filipinas (Folk Music of the Philippines). Madrid: Liberio de Fernando Fe.

Yalong, Bobby T. (2014). Flores de Mayo/ Santacruzan: The Queen of Filipino Festivities Asian Journal, www.AsianJournalMediaGroup.com.

\section{References from Thesis and Dissertations}

Buenconsejo, Jose Semblante (1993). The ted-em among the (Agusan) Manobo, Mindanao, southern Philippines: Musical and textual characteristics of an improvised discourse sung in in- and out-group performance context. M.A., University of Hawai'i.

De la Pena, La Verne David Carmen (2000).Traversing boundaries: A situated music approach to the study of day-eng performance among the Kankana-ey of northern Philippines. Ph.D., University of Hawai'i.

Grauberger, Stephen L. (1994). Diatonic harp of the Philippines: An historical overview and an organological comparison of the Cebuano-Bisayan harp. M.A., University of Hawai'i.

San Buenaventura, Steffi (1990). Nativism and ethnicity in a Filipino-American experience. Ph.D., University of Hawai'i. 